\title{
Noise Sources in the City: Characterization and Management Trends
}

\author{
Alice Elizabeth González \\ Environmental Engineering Department, IMFIA, Faculty of Engineering \\ Universidad de la República (UdelaR) \\ Uruguay
}

\section{Introduction}

Since man began to live sedentary, the noise in the city has been considered to be a more or less important source of annoyance. It is possible to find precedents about this subject in Greece and Rome, even before the beginning of the Christian Age. The proofs of this statement can be found in the Ancient Rome in Marcial's poetry texts about S. I b.C or in the regulations of Síbaris's city, Calabria -that was then included in the Magna Graecia- about year 600 b.C., that stated that no one could have cocks at home, and the "hammer workers" had to live outside of the city. Perhaps this is one of the oldest provisions that explicitly determine land use to noise pollution. It is also well known that, in the Middle Ages, it was forbidden to punish women at night time in London, to avoid disturbing noises (González, 2000).

Towards 1700 Bernardino Ramazzini, the "father" of the Occupational Medicine, stated for the first time the cause and effect relationship between occupational noise exposure and auditive damage. In his book "Of Morbis Artificum Diatribe" (1713), he explained this issue related to grain millers and bronze workers. About the "neighborhood of the coppersmiths" in Venice, Ramazzini wrote: "There are bronzesmiths in all the towns and in Venice they gather around only one neighborhood. They hammer there the entire day to give ductility to the bronze and to make metal jars with it. They also have their taverns and homes there, and they cause such an intense clatter that everyone runs away from such an annoying place" (González, 2000). It is interesting to note that noise appears for another time as a restriction for land use.

From the Middle Ages till the second half of the 19th century, the design and structure of the cities had suffered almost no changes. At the beginning of the Industrial Revolution, a process of disorderly and uncontrolled growth of urban centers emerged. People began to migrate "en masse" from countryside to the city, searching for new horizons and better job. This caused not only a fast growth of the urban population and of the built-up area, but also of the lots of problems derived from the lack of town planning and the overcrowded "around modernity".

The noise of the factories and the hustle derived from the people in the immediate areas deeply deteriorated the acoustic landscape of the cities. However, the noise and the black smoke from the chimneys of the factories were emblematic symbols that remained strongly associated with progress and economic improvement for a long time, even if these benefits were only for a little privileged part of the society. 
Technological development began to generate increasingly powerful -and, perhaps, progressively also cheaper- sources of noise that people at first thought to be related to job, then to progress and some years later, to comfort and social status. However, if technological and sociocultural development are taken into account, the main noise sources in the cities have remained the same throughout history: at s. I a.C., Séneca mentions that the main noise sources in the ancient Rome were the noise of the urban traffic ("the cars of the street"), the occupational noise and the leisure noise; at s. XXI b.C. these are still the main sources at our-days cities, as stated for many researchers (Beristáin, 2010; Madariaga Coaquira, 2008; González \& Echeverri, 2008). Face to this, it is not easy to share OrozcoMedina's affirmation: "The noise is an unwished by-product of the modern way of life" (OrozcoMedina \& Figueroa Montaño, 2010). Though her expression is harder, this idea is the same as Lizana's when referring "the acoustic costs associated with the progress" (perhaps in a wider historical sense). He also states: "The noise seems to be the most inoffensive of the pollutant agents" (Lizana, 2010).

Regarding the main noise sources in two Latin-American our-days cities, Madariaga Coaquira indicates that nowadays the main sources of urban noise in Arequipa's Peruvian city are the traffic (road, rail and air traffic), the announcements of fruit sale and other peddlers, the police whistle, the informal shops (bakeries, welding shops, shoe repair shops, carpentries), the social events and the artistic festivals (Madariaga Coaquira, 2008). In two papers of Beristáin about noise in Mexico City, one of them published twelve years later than the other, it is interesting to notice that main sources remain the same: road traffic and transportation, industrial and commercial places, formal and informal peddlers, public and private civil works, recreation places (discotheques, rock concerts, public and private meetings and parties, local village fairs, domestic household and neighborhood noise (Beristáin, 1998, 2010).

In general, three types of noise exposure can be clearly recognized in today society (CONICYT-IMFIA, 1998):

- Occupational exposure, that is motivated by work circumstances.

- Social exposure, which is voluntary and involves attendance to noisy places or the voluntary "consumption" (in a wide sense) of high levels of sound -for example, the use of personal music devices at high volume, the listening to loud music, the practice of sports like shooting, as well as other activities-.

- Environmental exposure, that is not voluntary in the sense of not being pursued by the person, but at the same time it is often inevitable. It is related to sound sources that are present in the environment where the person is -for example, traffic noise, music from stores, or neighborhood noises-.

\section{Noise sources in the city}

In order to describe them, the noise sources are often classified in three groups: stationary, mobile and collective sources (Miyara, 2008).

Stationary sources are those which, at the working scale, may be assumed as located at one fixed point of the space, for example a factory, a machine, a leisure place, a maneuvers zone. The civil works in urban zones can often be considered to be fixed sources.

Mobile sources instead, may also be assumed as point sources at the working scale, but they are allowed to move in the space. Is the case of road traffic, railroads and aircrafts. 
The collective sources are the result of the accumulation of sources in public spaces, for example, the people in the street, a village fair, a public meeting, a city square or a popular celebration.

From another point of view, noise sources in the cities may be related to traffic and transportation, leisure, work, community services and neighborhood.

\subsection{Traffic}

There is no doubt that the main source of noise in the city is road traffic. Orozco-Medina reports studies from Costabal and Fagúndez showing that traffic is responsible for about 70 $\%$ of the urban noise. The major part of it comes from motor vehicles and the most relevant sources are the heavy motor vehicles, including public transport (Orozco-Medina \& Figueroa Montaño, 2010).

The maritime or fluvial transport only has incidence in port cities and only near the port facilities. The air transport is the main noise source in the zones near the airports or close to the air routes. Neither the airports might be built extremely close to the cities nor the air routes be designed passing over urban areas.

In the cities where the railway is a popular transport system -for example, the metro or the subway- the whole systems had to be modernized to satisfy current environmental standards. As a consequence, most of the urban rail systems were enhanced to fulfill lower noise standards; then, they turned to reasonable noise levels. However, some very noisy trains are still running, especially in subway lines. An emblematic case is the extremely noisy subway service of Buenos Aires city in Argentine.

As it is consented worldwide, the expression "traffic noise" refers to engine and tyre noise from vehicles. But other elements should be considered to occur, as loud sound from brakes, noisy exhausts and claxons (horns), whose incidence depends on the fleet age, the driving style and the existence, fulfillment and control of a suitable regulation (González, 2000; Orozco-Medina \& Figueroa-Montaño, 2010; Sanz Sa, 2008). Nowadays, researchers work on the development of vehicles powered by alternative energy sources, to reduce the dependence on fossil fuels. Some of them have another environmental advantage besides the reduction of the gases and particulate matter emissions: they are more silent. Complaints did not wait: the detractors of hybrid and electric vehicles got strongly queried the safety of a silent transport system (Observatorio de las novedades acústicas y musicales, 2010).

Regulating traffic noise is not simple, but necessary. Already in the Ancient Rome, transport regulation was needed to forbid driving during the night, to avoid disturbing people during their rest hours (Orozco-Medina \& Figueroa Montaño, 2010). Currently, the standards tend to set the admissible noise emission levels for each vehicle according to its gross weight, its engine and number of seats. To know the actual noise emission level, static or dynamic tests according to international standard procedures should be performed (for example, ISO 5130: 2007 for stationary test and ISO 362:2009 for dynamic tests) (González et al., 2008).

On the other hand, the control and management of traffic noise should tend to protect public health, but even if some exceptions can be found (and it is not possible to fulfill their requirements) there has no sense to limit traffic noise as a whole (González et al., 2008). Nevertheless, some management measures that are not designed to control or to diminish the traffic noise in the cities can reach good results in this sense; it is the case of the traffic 
regulation known as "pico y placa"1 in Medellín city, Colombia (Ríos Valencia, 2008). Some aspects that should be taken into account when dealing with traffic noise in the cities are discussed in Section 4.

\subsection{Ambient noise from industries and commerce}

Among the noise stationary sources, major cases are the industrial and trade facilities and the leisure places. These are not the only ones: if they last for a long time, the civil works in the city would be considered as stationary sources (CONICYT-IMFIA, 1998; IMM-Facultad de Ingeniería, 1999). This section is referred to ambient noise that industrial and trade facilities generate close to their location, but not to the occupational exposure of workers.

The noise troubles caused by industrial and trade facilities must consider three aspects: the propagation of the noise from the operation of the company as a stationary source and aiming for the fulfillment of regulations; the noise of the induced traffic, whose spatial scale is undoubtedly larger, and that must be added to the preexisting traffic noise; and the noise associated with the parking lots and loading and unloading zones, whose extension and dynamics should be carefully analyzed case by case in order to identify their levels of activity at different times.

Contrary to intuition, the control of environmental noise associated with the operation of large and medium industries is not the major problem to manage about stationary sources, due to the fact that the own scale of the company allows it to invest to meet current regulations. This is not only the best from the legal standpoint, but also the company can reduce or even avoid troubles that could occur later because of complaints from neighbors. In the same sense, Lizana indicates that, unlike the large factories, the small and medium-sized shops and industries are distributed all around the city, so their indirect impacts caused by the transport of materials and products affect bigger areas (Lizana, 2010). Sometimes is easy to find loudspeakers out of small shops emitting music or announcing the sales to attract people that walk by (Beristáin, 2010), often making trouble with the neighbors. In fact, the hardest problems to manage derive from the small shops working in noisy activities. Their small scale, even artisanal, often put them out of the formal working system. For these companies, fulfilling noise regulations is usually very difficult, and they often break them (Beristáin, 2010). Nevertheless, the highest levels of noise related to big malls and hypermarkets occur inside: they are designed with basis on detailed psychology and marketing studies to satisfy fun and shopping expectation of clients. The major troubles with the neighbors may be caused by the continuous operation of air conditioning equipment, compressors and others, which run 24 hours a day, so their noise emission, that often has startings and stops, becomes much more evident in the night, when the city noise levels are low.

Noise from the loading and unloading areas usually offers true challenges to manage. It involves not only heavy traffic but trucks waiting with running engines, loud voices, horselaughs, shouts, blows and other events almost inseparable from these affairs. In turn, loads management usually is not performed by the main entrance of the company but by its back entrance. This usually stimulates the spontaneity of workers, in terms of their verbal communication and how to perform their tasks.

1"Pico y placa" (peak and plate) means "rush hour and plate": according to the type of vehicle, the last number of its plate and the day of the week, one vehicle can or cannot run during morning and afternoon rush hours. 
When perimeter barriers are built with the main objective of reducing the visibility towards the inland of the company or harmonizing with the surrounding landscape, many times they can also serve as acoustic barriers. This is the case of landscaped embankments when it is possible to build them, or perimeter walls of height and design compatible with those from the buildings, attending to aesthetic criteria and current urban development regulations. The acoustic attenuation provided for these barriers could be calculated.

The incorporation of plant species to improve the appearance of a non-acoustic barrier should be always a good idea, especially in urban areas. Though, a green curtain or a vegetal barrier designed to have an acoustic function should not be confused with an aesthetic one. Indeed, according to the statements of Kotzen and English, plants and trees must meet certain characteristics to make feasible their use in acoustic barriers. According to them, with basis on experimental studies developed between 1980 and 1990, the effectiveness of plant curtains between $15 \mathrm{~m}$ and $40 \mathrm{~m}$ thickness is greater at $250 \mathrm{~Hz}$ and above $1000 \mathrm{~Hz}$, but they warn that their maximum attenuation is about $3 \mathrm{~dB}$ in $\mathrm{L}_{\text {Aeq. }}$. These researchers also state that the maximum attenuation performance of a green barrier occurs at a wavelength twice the size of the leaves of the tree species considered (Kotzen \& English, 2009).

Recent experimental studies carried out in Colombia did not find statistically significant differences between sound levels measured at a distance of $10 \mathrm{~m}$ from the same highway in four areas with different vegetation: low height pasture (control area), trees over $5 \mathrm{~m}$ high, shrub (species less than $5 \mathrm{~m}$ height and branched from the base), and an area with both trees and shrub (Posada et al., 2009).

\subsection{Leisure noise}

The voluntary assistance to noisy places, or "voluntary consumption of noise", is the main face of social exposure to noise. Most of the young people are not only voluntarily exposed to noise but they also generate it: music, voice tone, lifestyle and entertainments are noisier every day. This section is addressed to the management of noise troubles at the so called "pink zones", the zones of the cities where nightlife and leisure places are the main stars.

The noise produced by different amusement activities in the night is a growing concern for city managers. While historically the main challenge was to oblige all leisure places to have a proper acoustic isolation to avoid generating high sound levels in neighbors' houses, other conflicts and problems have emerged in recent years (González \& Echeverri, 2008).

The noise problem was first centered on the fact that the recreation places had to have satisfactory isolation conditions to assure the resting of the next door neighbors. The main difficulties for the management at that time were related to having good acoustical projects, building them properly, planning the needed investments in a reasonable time (sometimes they might be really expensive) and controlling their performance in service. Even when significant investments are required, these could avoid or end with neighborhood troubles. In one case that was recently discussed, the updating of a big non-isolated building chosen to installing a nightclub to a double wall place, with double ceiling and forced ventilation system, resulted in costs equal to one month ticket sales. This issue will be deeper presented in Section 3.

\subsection{Construction of civil works}

The construction of public and private civil works in the urban areas can become in practice "stationary sources" of noise, especially when the construction stage lasts for a long time, 
regardless of the causes for this to happen (CONICYT-IMFIA, 1998; IMM-Facultad de Ingeniería, 1999). But even if they do not last more than the strict necessary time, these activities are often annoying for the neighbors because of the noise of machinery or other activities inherent to the works.

To shorten the construction timing, sometimes people should work not only during the daytime. In some cases, especially when works involve high traffic streets, many labors should be performed only during nighttime to minimize traffic and safety problems (Beristáin, 2010).

Noise levels related to civil works machinery differ from one machine to another. Table 1 presents the acoustic power levels for some machines, as they are stated in the Directive 2005/88/EC relating to the noise emission to the environment by equipment used outdoors.

In some cases, construction companies choose to adopt measures to reduce community impact of the noise from works they perform. For instance, it is the case of "Empresas Públicas de Medellín E.S.P." (Public Companies of Medellín), Colombia: since the company has reviewed its Standards and Specifications for General Construction, the NEGC 1300 ("Environmental management in public services facilities"), a chapter concerning on "Community Impact" was added. It defines five main action areas: community relations; urban environmental management; road safety and signalization; social security wage and industrial safety management in the construction place (Giraldo Arango, 2008).

As Giraldo Arango refers, the experiences of the company in incorporating management guidelines defined by needs of social responsibility and environmental management have shown that, in some cases, works have not become more expensive: just the opposite, the changes have allowed saving money and runtime in some works, as well as reducing conflicts with the neighborhood. He remarks that the performed changes also have caused the reduction of noise levels in areas close to the construction site. The company has incorporated new environmental management requirements in its works specifications: the use of modern machinery and equipment with soundproofed engines; preventive and corrective maintenance measures to keep them in proper conditions; when it is not possible to isolate the sound emission of a jackhammer or the disc from a cutter, maximum lasting of shifts of two continued hours for equipment whose noise emissions exceed the permitted standards, with breaks of the same duration; coordination of schedules with the heads of near educational and health institutions, aiming at doing pavement cuts during class breaks or shift changes. Giraldo Arango states: "While it is true that some equipment and machinery used by the civil works construction sector are noisy, in both the public and the private sector some statements mention the impossibility of controlling their noise levels. This opinion is only partially true, since it has been proved that is possible in practice to use other methods as those normally used, and which are environmentally and economically even more attractive". He highlights the importance of preventive maintenance of equipment and machinery, as well as the need of a greater control about environmental management. In his opinion, control activities should be assumed by the hiring entities (Giraldo Arango, 2008).

Table 2 presents some noise measurements carried up at Montevideo, Uruguay, in 2010, one meter away from two wellpoint pumps of the same characteristics, which were being used to depress the water table level. One of them was into an acoustic encapsulation and the other was not. Both equipments belong to the same company and were working at the same time in similar works at the same area of the city. 


\begin{tabular}{|c|c|c|c|}
\hline \multirow{2}{*}{ Type of equipment } & \multirow{2}{*}{$\begin{array}{l}\text { Net installed power } \mathrm{P}(\mathrm{kW}) \\
\text { Electric power } \mathrm{Pel}_{\mathrm{el}} \text { in } \mathrm{kW}(1) \\
\text { Mass of appliance } \mathrm{m} \text { in } \mathrm{kg} \\
\text { Cutting width L in cm }\end{array}$} & \multicolumn{2}{|c|}{$\begin{array}{l}\text { Permissible sound power levels in } \\
\mathrm{dB} / 1 \mathrm{pW}\end{array}$} \\
\hline & & $\begin{array}{l}\text { Stage I as from } \\
\text { January } 3,2002\end{array}$ & $\begin{array}{l}\text { Stage II as from } \\
\text { January } 3,2006\end{array}$ \\
\hline \multirow{3}{*}{$\begin{array}{l}\text { Compaction machines (vibrating } \\
\text { rollers, vibratory plates, vibratory } \\
\text { rammers) }\end{array}$} & $P \leq 8$ & 108 & $105^{(2)}$ \\
\hline & $8<\mathrm{P} \leq 70$ & 109 & $106^{(2)}$ \\
\hline & $P>70$ & $89+11 \lg P$ & $86+11 \lg P(2)$ \\
\hline \multirow{2}{*}{$\begin{array}{l}\text { Tracked dozers, tracked loaders, } \\
\text { tracked excavator-loaders }\end{array}$} & $P \leq 55$ & 106 & $103^{(2)}$ \\
\hline & $P>55$ & $87+11 \lg P$ & $84+11 \lg P(2)$ \\
\hline \multirow[b]{2}{*}{$\begin{array}{l}\text { Wheeled dozers, wheeled loaders, } \\
\text { wheeled excavator-loaders, dumpers, } \\
\text { graders, loader-type landfill } \\
\text { compactors, combustion-engine driven } \\
\text { counterbalanced lift trucks, mobile } \\
\text { cranes, compaction machines (non- } \\
\text { vibrating rollers), paver-finishers, } \\
\text { hydraulic power packs }\end{array}$} & $P \leq 55$ & 104 & $101^{(2)(3)}$ \\
\hline & $P>55$ & $85+11 \lg P$ & $82+11 \lg P^{(2)(3)}$ \\
\hline \multirow{2}{*}{$\begin{array}{l}\text { Excavators, builders' hoists for the } \\
\text { transport of goods, construction } \\
\text { winches, motor hoes }\end{array}$} & $P \leq 15$ & 96 & 93 \\
\hline & $P>15$ & $83+11 \lg P$ & $80+11 \lg P$ \\
\hline \multirow{3}{*}{ Hand-held concrete-breakers and picks } & $m \leq 15$ & 107 & 105 \\
\hline & $15<\mathrm{m}<30$ & $94+11 \lg m$ & $92+11 \lg m^{(2)}$ \\
\hline & $m>30$ & $96+11 \lg m$ & $94+11 \lg m$ \\
\hline Tower cranes & & $98+\lg P$ & $96+\lg P$ \\
\hline \multirow{3}{*}{ Welding and power generators } & $\mathrm{P}_{\mathrm{el}} \leq 2$ & $97+\lg P_{\mathrm{el}}$ & $95+\lg \mathrm{P}_{\mathrm{el}}$ \\
\hline & $2<\mathrm{P}_{\mathrm{el}} \leq 10$ & $98+\lg \mathrm{P}_{\mathrm{el}}$ & $96+\lg \mathrm{P}_{\mathrm{el}} \mathrm{P}_{\mathrm{el}}$ \\
\hline & $10>\mathrm{P}_{\mathrm{el}}$ & $97+\lg \mathrm{P}_{\mathrm{el}}$ & $95+\lg \mathrm{P}_{\mathrm{el}}$ \\
\hline \multirow{2}{*}{ Compressors } & $P \leq 15$ & 99 & 97 \\
\hline & $P>15$ & $97+2 \lg P$ & $95+2 \lg P$ \\
\hline \multirow{4}{*}{$\begin{array}{l}\text { Lawnmowers, lawn trimmers/lawn- } \\
\text { edge trimmers }\end{array}$} & $50<L \leq 70$ & 100 & 98 \\
\hline & $70<L \leq 120$ & 100 & $98^{(2)}$ \\
\hline & $L>120$ & 105 & $103^{(2)}$ \\
\hline & $L \leq 50$ & 96 & $94(2)$ \\
\hline
\end{tabular}

(1) $\mathrm{P}_{\mathrm{el}}$ for welding generators: conventional welding current multiplied by the conventional load voltage for the lowest value of the duty factor given by the manufacturer.

$\mathrm{P}_{\mathrm{el}}$ for power generators: prime power according to ISO 8528-1: 1993, clause 13.3.2

(2)The figures for stage II are merely indicative for the following types of equipment:

- $\quad$ walk-behind vibrating rollers;

- $\quad$ vibratory plates $(>3 \mathrm{k} \mathrm{W})$;

- vibratory rammers;

- dozers (steel tracked);

- $\quad$ loaders (steel tracked > $55 \mathrm{~kW}$ );

- combustion-engine driven counterbalanced lift trucks;

- compacting screed paver-finishers;

- $\quad$ hand-held internal combustion-engine concrete-breakers and picks $(15<\mathrm{m}<30)$

- lawnmowers, lawn trimmers/lawn-edge trimmers.

Definitive figures will depend on amendment of the Directive following the report required in Article 20(1). In the absence of any such amendment, the figures for stage I will continue to apply for stage II.

(3)For single-engine mobile cranes, the figures for stage I shall continue to apply until 3 January 2008. After that date, stage II figures shall apply.

The permissible sound power level shall be rounded up or down to the nearest integer number (less than 0,5 , use lower number; greater than or equal to 0,5 , use higher number)

Table 1. Admissible levels of acoustic power for machines of functioning outdoors according to Directive 2005/88/EC. 


\begin{tabular}{|c|c|c|c|c|}
\hline & \begin{tabular}{|c|} 
Non \\
encapsulated \\
machine
\end{tabular} & $\begin{array}{c}\text { Encapsulated } \\
\text { machine }\end{array}$ & Difference & Observations \\
\hline L LAFmáx & 87,2 & 77,1 & $-10,1$ & Significant attenuation \\
\hline LAFmín & 82,6 & 74,3 & $-8,3$ & Significant attenuation \\
\hline $\mathrm{L}_{\text {Aleq }}$ & 86,4 & 76,4 & $-10,0$ & Significant attenuation \\
\hline $\mathrm{L}_{\mathrm{AFeq}}$ & 84,8 & 75,5 & $-9,3$ & Significant attenuation \\
\hline $\mathrm{L}_{\mathrm{CFeq}}$ & 91,1 & 90,2 & $-0,9$ & $\begin{array}{c}\text { As it is expected, the encapsulation is } \\
\text { not effective at low frequencies. }\end{array}$ \\
\hline $\mathrm{L}_{\mathrm{AF} 5}$ & 85,6 & 76,0 & $-9,6$ & Significant attenuation \\
\hline $\mathrm{L}_{\mathrm{AF} 10}$ & 85,4 & 75,9 & $-9,5$ & Significant attenuation \\
\hline $\mathrm{L}_{\mathrm{AF} 50}$ & 84,8 & 75,5 & $-9,3$ & Significant attenuation \\
\hline $\mathrm{L}_{\mathrm{AF} 90}$ & 84,1 & 75,1 & $-9,0$ & Significant attenuation \\
\hline $\mathrm{L}_{\mathrm{AF} 95}$ & 83,9 & 75,0 & $-8,9$ & Significant attenuation \\
\hline $\mathrm{L}_{\mathrm{AIeq}}-\mathrm{L}_{\mathrm{AFeq}}$ & 1,6 & 1,0 & $-0,6$ & $\begin{array}{c}\text { As } L_{\text {AFeq }} \text { and } L_{\text {Aleq }} \text { have had similar } \\
\text { decreases, then impulsivity is only } \\
\text { slightly reduced. Not a significant } \\
\text { variation is found. }\end{array}$ \\
\hline $\mathrm{L}_{\mathrm{CFeq}}-\mathrm{L}_{\mathrm{AFeq}}$ & 6,3 & 14,8 & $+8,5$ & $\begin{array}{l}\text { As the encapsulation is not effective at } \\
\text { low frequencies, noise levels } \\
\text { expressed in dBC differ much more } \\
\text { with the same levels expressed in dBA } \\
\text { when the equipment is encapsulated. }\end{array}$ \\
\hline $\begin{array}{c}\left(\mathrm{L}_{\mathrm{AF} 10}-\right. \\
\left.\mathrm{L}_{\mathrm{AF} 90}\right)\end{array}$ & 1,3 & 0,8 & $-0,5$ & $\begin{array}{l}\text { As } L_{A F 10} \text { and } L_{A F 90} \text { have had similar } \\
\text { decreases, then is only slightly } \\
\text { reduced. Not a significant variation is } \\
\text { found. }\end{array}$ \\
\hline
\end{tabular}

Table 2. Comparison of the acoustic performances of two well point pumps, one of them into an acoustic encapsulation.

All the measures were done with a type 1 sound level meter, with time responses fast, slow and impulse in real time, frequency weighting scales $\mathrm{A}$ and $\mathrm{C}$ and third-octave bands analysis also in real time. The attenuation of sound levels due to the acoustic encapsulation in the immediate environment is important in most of the measured parameters: it is about 9 $\mathrm{dB}$ regarding the energy levels $\left(\mathrm{L}_{\mathrm{Aeq}}\right)$ and also regarding the statistic ones (the permanence levels that were considered are $\left.\mathrm{L}_{\mathrm{AF} 5}, \mathrm{~L}_{\mathrm{AF} 10}, \mathrm{~L}_{\mathrm{AF} 50}, \mathrm{~L}_{\mathrm{AF} 90}, \mathrm{~L}_{\mathrm{AF} 95}\right)$. As expected, this does not happen with the parameters measured with $C$ frequency weighting, that have worse response to the acoustic protection (González, 2010b).

\subsection{Fairs and markets}

Even though the neighbourhood fairs and markets are referred as part of the agents of lower acoustic impacts on the city regarding their scope and number of affected people (OrozcoMedina \& Figueroa-Montaño, 2010), they often result in troubles that sometimes should turn into neighbourhood conflicts (Defensoría del Vecino de Montevideo, 2010). 
Because of their function they must be installed within residential areas, and their performance and schedule are often the main causes of noise complaints. Management measures, then, can only be derived from agreements with and within neighbours. In Montevideo, Uruguay, with the increase in complaints in this regard, the Ombudsman's Neighbour organized a seminar to discuss this issue. The recommendations of the seminar aimed to generate a fair rotation schedule between different streets of the neighbourhood they serve. In a period of few months, twelve fairs were transferred from their usual places to other ones nearby (Defensoría del Vecino de Montevideo, 2010).

\subsection{Popular celebrations, artistic festivals}

Day to day, the artistic festivals congregate more people. Beginners or consecrated, most of musicians use to take part in these events that are the major way for the firsts to be known or for the idols to be in close contact to their fans. Bigger and bigger places are needed to perform these festivals. As it might be suspected, the biggest ones are open places (stadiums or parks, for example), and obviously they are not soundproof places. Not only the wellknown complaints about noise and safety might accompany these events: for instance, also bizarre conflicts may take place. In December of 2000, a great music festival that was attended by 90.000 people was performed at the hippodrome of Rosario city, Argentine. No one from the organization team remembered that also about 500 race horses were in the stables at the same time. The animals virtually madden with such a high noise and they tried to escape, clashing one and another time against the walls and gates, till many of them resulted severely hurt (Laboratorio de Acústica y Electroacústica, 2011).

Many societies have traditional cultural events that in many of the cases are accompanied by high levels of noise. Historically they have been considered as activities of interest to preserve and even potentiate to strengthen the local identity (Brito, 2011a; Defensor del Pueblo de Madrid, 2005). Nowadays, the increasing number of complaints and even trials about excessive noise levels, has forced the Administration to amend its legislation as a preventive way for preempting such actions.

For instance, in 2007 the trial judges banned the celebrations of the Carnival of Tenerife by excessive noise, based on a lawsuit filed by neighbors and a socially controversial trouble was installed (Diario El País, 2007). Then Valencia authorities preemptively conquered exceptions in terms of noise levels for 13 public celebrations, including the Fallas. These are particularly noisy, because of the pyrotechnics great display that happens at the climax of the celebration. Without referring to extreme noise levels, which often largely exceed 100 $\mathrm{dBA}$, in an interview carried by the Official College of Industrial Superior Engineerings in 2004, Gaja said: "The ideal average decibel is setted at a maximum of 65 for the day and 45 for the night but the main streets of the city always vary between 70 and $75 \mathrm{dBA}$; this level not lowers than 80 during celebrations of Fallas" (Colegio Oficial de Ingenieros Superiores Industriales de la Comunidad Valenciana, 2004). Figure 1 present daily records of $L_{\text {Aeq }}$ at the Plaza of España, Valencia. The atypical noise levels in March are clearly shown. The peaks are given by the celebrations of Fallas (Gaja et al., 2003).

An exhaustive report about noise pollution was published by the Ombusdman of Madrid, Spain. In this detailed document, the Ombusdman discusses almost all the expected troubles about noise (and some not so expected) in today Madrid's society. He puts in the shoes of the different social actors to present an overview as complete as possible of each case, taking into account not only legal and technical issues, but also health, ethics, economics and social 
ones. Management of urban noise is not an easy task. Referring to popular celebrations, he says: "the occasional noise is noise anyway" (Defensor del Pueblo de Madrid, 2005).

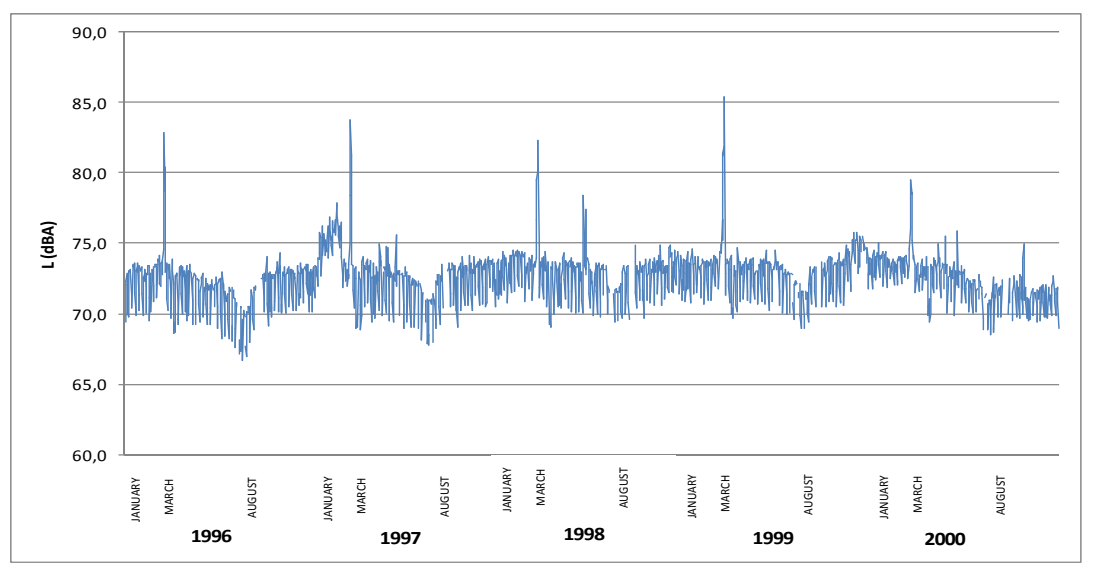

Fig. 1. $\mathrm{L}_{\mathrm{Aeq}, 24 \mathrm{~h}}$ at the Plaza Mayor of Valencia, Spain.

\subsection{Community services: Street sweeping, solid waste collection}

Some community services are inevitably associated with noises whose levels may disturb the neighborhood. Sometimes they can be minimized, but to achieve this, deep changes are required about the way the service is provided. For example, to avoid the noises caused by the mechanical sweeping of streets, a more frequent manual sweeping service could be considered. Waste collection services, either domestic or special, should not be intended only as a noise issue about slow heavy traffic. There are different options for waste collection. The selection of one or another usually does not depend on the noise levels of them. Once the decision is made, the features of the selected option also define the sources and levels of noise that will be involved.

The elimination of noise sources from prevailing collecting system not always is possible. The proper planning and operation of the service and the preventive maintenance of all the equipment and vehicles assigned to it are the most effective ways to minimize noise impacts in the neighborhood.

\subsection{Other noises in the neighborhood}

All the sources of noise that affect a certain place are part of the environmental noise at it. Their interactions result in the so called "acoustic landscape", that is an expression of the "acoustic identity" of the place in a certain time.

The particular characteristics of each society can define its quotidian noise levels. These are associated with factors such as lifestyle, cultural patterns, socio-economic development, technification level, among others; these factors also have incidence on the environmental noise levels that the society could accept. Once their basic living needs are satisfied, people begin to aim for a better life quality. The acoustic comfort is one of the most appreciated aspects that people aim to conquer for improving their quality of life. Not in vane Robert Koch said: "The day will come when people begin to fight the noise as they do so against cholera and pest" (González, 2000). 
Other agents that are included in the list of sound sources of reduced scope, that cause only minor impacts and which shape the details of the sound landscape from of each place, are for instance the crying of children, street sales, peddlers and sounds caused by pets (OrozcoMedina \& Figueroa-Montaño, 2010). While these elements cause minor local impacts, they appear all the time as annoying elements for people in different cities, as Arequipa, Perú (Madariaga Coaquira, 2008) or Montevideo, Uruguay (CONICYT-IMFIA, 1998; González et al., 1997). In fact, the first acoustic map of Montevideo conducted between 1997 and 1998 by the modality of selected points that were chosen by the Municipality, has evidenced that the main source of noise annoyance in some neighbourhoods was the barking of dogs (CONICYT-IMFIA, 1998).

Referring to household appliances and increasingly powerful audio devices, Beristáin said: "Modernity has brought some comfort to the houses of many people, but also has brought continuous and intermittent noises, and often times, high sound levels" (Beristáin, 2010).

In one of his masterpieces, Milan Kundera says: "Noise has one advantage. You cannot listen the words". This thought highlights the paradigm of isolation that is increasingly affecting the present society. About this issue, Miyara affirmed: "The high cultural noise level threatens the ability to think, to make critical judgments about things, including the annoyance of having permanently invaded the own acoustic space. It also tends to the isolation of people. There are studies that suggest an inverse connection between sound level and interpersonal solidarity" (González, 2000). Later, he confirms and argues about the connection between exposure to high noise levels and aggressiveness (Miyara, 2007).

\section{Nightlife and noise of leisure}

Conflicts with neighbors from "pink zones" become more intense and frequent day by day, not only because of the high noise levels in the environment but also by other troubles, including safety ones. In countries such as Spain, this concern began to be handled more than twenty years ago, with systematic and strong measures, such as the creation of the ZAS, the "acoustically saturated zones" (Gaja et al., 1998). In some Latin American countries including Argentina, Brazil, Colombia, Uruguay, the pink zones are still one of the main noise problems in urban areas regardless of their size, and also a very complex challenge to deal with (Beristáin, 2010; Brito, 2011a, 2011b; González et al., 2006; González \& Echeverri, 2008).

Supposing that acoustic isolation requirements are fulfilled, there are still two kind of remaining problems: infrastructure problems and operation ones.

One of the main infrastructure problems related with leisure locals is related to the need for parking spaces for the assistants. This has become a "key requirement" to fulfill in order to avoid adverse impacts on the influence area and also to control the expansion of this area. Indeed, when parking lot places are scarce, the noise problem spreads from the site to their surroundings, because people not only park near the site but also far away from it. The influence area of induced traffic grows, often with significant presence of very noisy motorbikes with forbidden free escapes. While many leisure places fail to meet the requirement of the parking lot places due to its location, but perhaps it is not convenient to force them to move to another place because of their long permanence in a certain point of the city, some municipalities require hiring a private security company to quickly disperse the people who is out of the local and to avoid the occurrence of unwanted noises in the street (González et al., 2006; González \&.Echeverri, 2008). 
About the operational problems related to pink zones, there are two major issues: the accumulation of youths outside the nightlife clubs, and the circulating vehicles -or even parked ones- with powerful audio equipments turned on. About the accumulation of people outside the locals, there are two peak periods: before the opening, when there is a huge mass of young people waiting for accessing and at the closing time. Even though in the first case, people are usually not drunk nor under the effects of other drugs, the adrenaline rush and the anonymity of mass leads to the occurrence of shouts and songs that will undoubtedly generate annoyance to the neighborhood. While the night is going on, the need to go out to smoke because of the prohibition of smoking inside locals of public use, creates a new focus of people, sometimes encouraged by the weather conditions that make the cool night air more attractive for a while than the foul air at dancing. Then, gradually the number of people at the street increases (González \&.Echeverri, 2008).

At first, noises are only derived from the communication between people. When they begin to long for high noise levels, motorcycles with noisy free escapes and music from parked or in circulation vehicles with powerful audio devices begin to be heard at high volume. In these cases, the imposition of having a hired private security service has had little effect: young people can always move to establish their "camp" further away from the nightclub, out of the effective controlled area. And so far, it has not been possible that these situations are taken as public order issues, which is the only case in which the police, as the official law enforcement agent, should proceed (González et al., 2006).

The problems associated with entertainment generate different reactions. In Spain there is a non-profit organization, PEACRAM (Plataforma Estatal de Asociaciones contra el Ruido y las Actividades Molestas - National Movement of Civil Associations against Noise and Annoying Activities), where people who feel "acoustically abused" are grouped. In the opening speech of their first congress held in Zaragoza, Spain, in 2004, it was reported that noise was the major environmental pollutant in Spain, on the basis of the number of complaints. In turn, they qualified it as "the most socially unsupportive pollutant". Sáenz Cosculluela, whose conference opened the congress, has referred to some issues related to solidarity and coexistence. He highlighted the problems of urban planning that allow the installation and even the proliferation of nightclubs in residential areas, calling the authorities to respect the "fundamental rights of the neighbors", which "take precedence over any other rights and are a non-negotiable matter". He qualified the current entertainment model as "unbearable", and he claimed for effective management measures, such as less operation hours for entertainment places, increased distances to residential areas, denial of licenses for installing new leisure locals, new urban planning regulations, or diversification of main trades of shops in commercial zones. Sáenz Cosculluela stated that "the leisure noise is the noise pollution form that attempts more directly against civic life and against the main rights of citizens, therefore the noise management approach from the environmental or from the health point of view, is not sufficient and it needs to be supplemented with approaches from ethics, civism and political points of view through the prism of human dignity, freedom and democracy" (Sáenz Cosculluela, 2004).

The management tools for leisure noise should consider the need for a solid municipal structure about licenses for the installation of leisure places and for revision and control of acoustic projects, inspection capabilities, appropriate quality and quantity equipment, regulations on land use, timetable and duty bonification program (or another kind of benefit or bonification program) for the relocation of existing facilities, all of these supported on by ongoing training of technical and semi-technical human resources (González \& Echeverri, 2008). 
A study about noise levels during nighttime in Salto city (Uruguay) was carried out in 2005, aiming to aware the decision-makers about the need to review the management of issues related to night leisure places. Four measurement points were selected: three of them (numered from 1 to 3 ) were chosen in the pink zone in the downtown -being point 2 the most impacted due to the fact that it was close of two nightclubs with great public success-; a control point was selected (point 4), in an area theoretically not affected by the night recreational activities (González et al., 2006). Environmental noise measurements lasting 30 minutes were carried out at each point in four shifts (between 9 $\mathrm{PM}$ and $11 \mathrm{PM}$, later designated as $10 \mathrm{PM}$; between 11 PM and $1 \mathrm{AM}$, later designated as 12 PM; between 1 AM and 3 AM, later designated as 2 AM and between 3 AM and 5 AM, later designated as $4 \mathrm{AM}$ ). To describe the condition without the operation of leisure locals, measurements were made on Mondays, Tuesdays and Wednesdays at all points and shifts. To describe the condition corresponding to the operation of leisure locals, measurements were carried out on Saturdays and Sundays, at all the points and shifts considered before. Measurements were made with a Type 2 integrating sound level meter owned by the municipality. In all cases the selected frequency weighting scale was "A" and the selected response time was Fast. Data from second to second were saved on an informatics device for further processing.
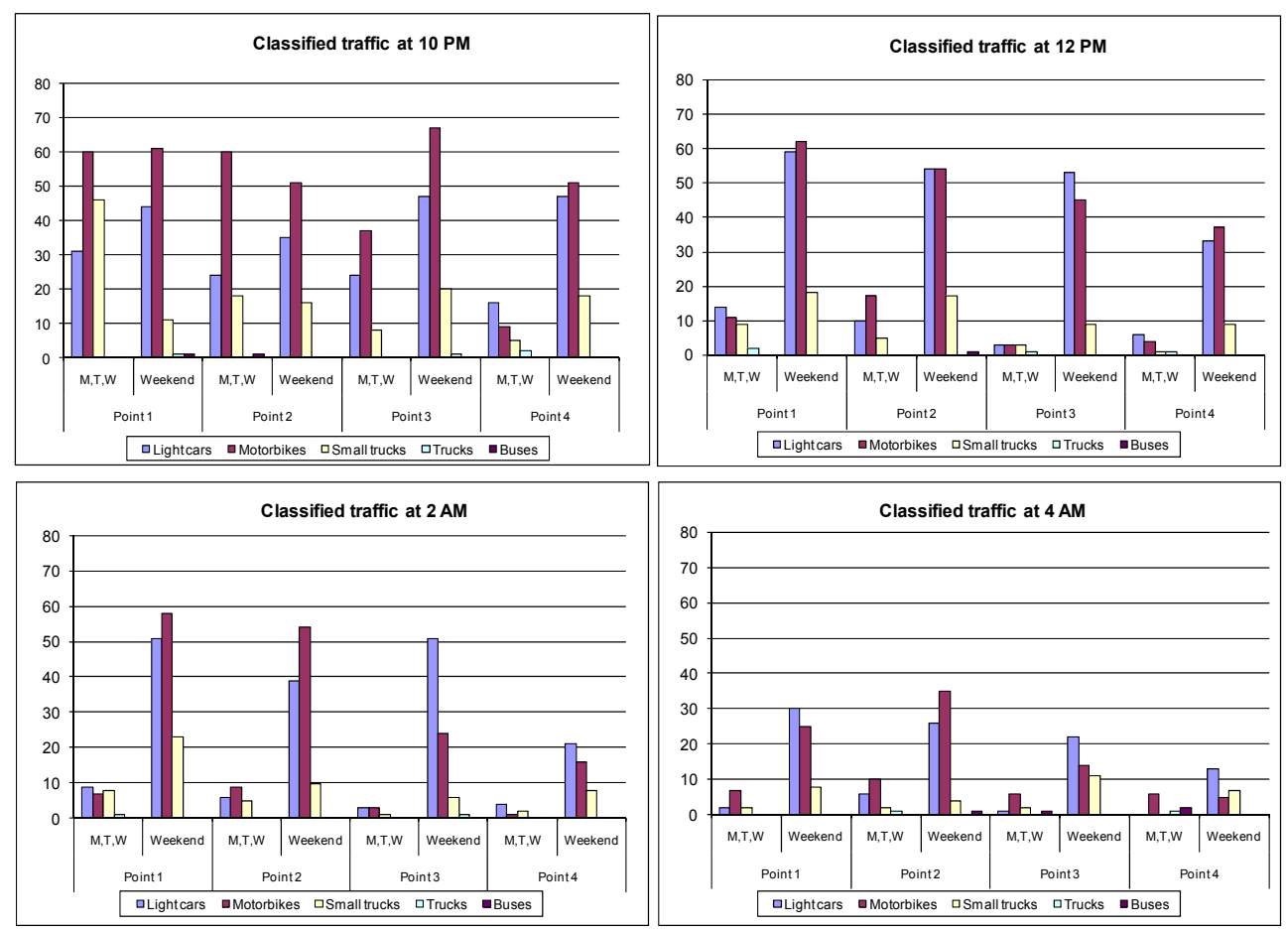

Fig. 2. Classified traffic at different points of measurement and hours, with and without nightclubs operation. 
Main results are shown in figures 2 and 3, and are summarized next (González et al., 2006):

- Traffic is directly related to the activity of the nightclubs. When they are not in operation, the traffic is very low and the same happens with the noise levels.

- There is no difference between nights with and without nightclubs in operation at 10 PM.

- A great difference on $\mathrm{L}_{\mathrm{AF} 90}$ values is observed in points 1 to 3 between conditions with and without nightclubs in operation.

- When nightclubs are in operation, the $\mathrm{L}_{\mathrm{AF} 90}$ values in points 1 to 3 usually exceed 55 $\mathrm{dBA}$, the noise level value stated by the municipal regulations to meet in open places during the night.

- The minimum impact caused by the nightclubs in operation is registered at 10 PM.

- The most affected hour by nightclubs in operation is $2 \mathrm{AM}$, both in terms of traffic and of noise levels.
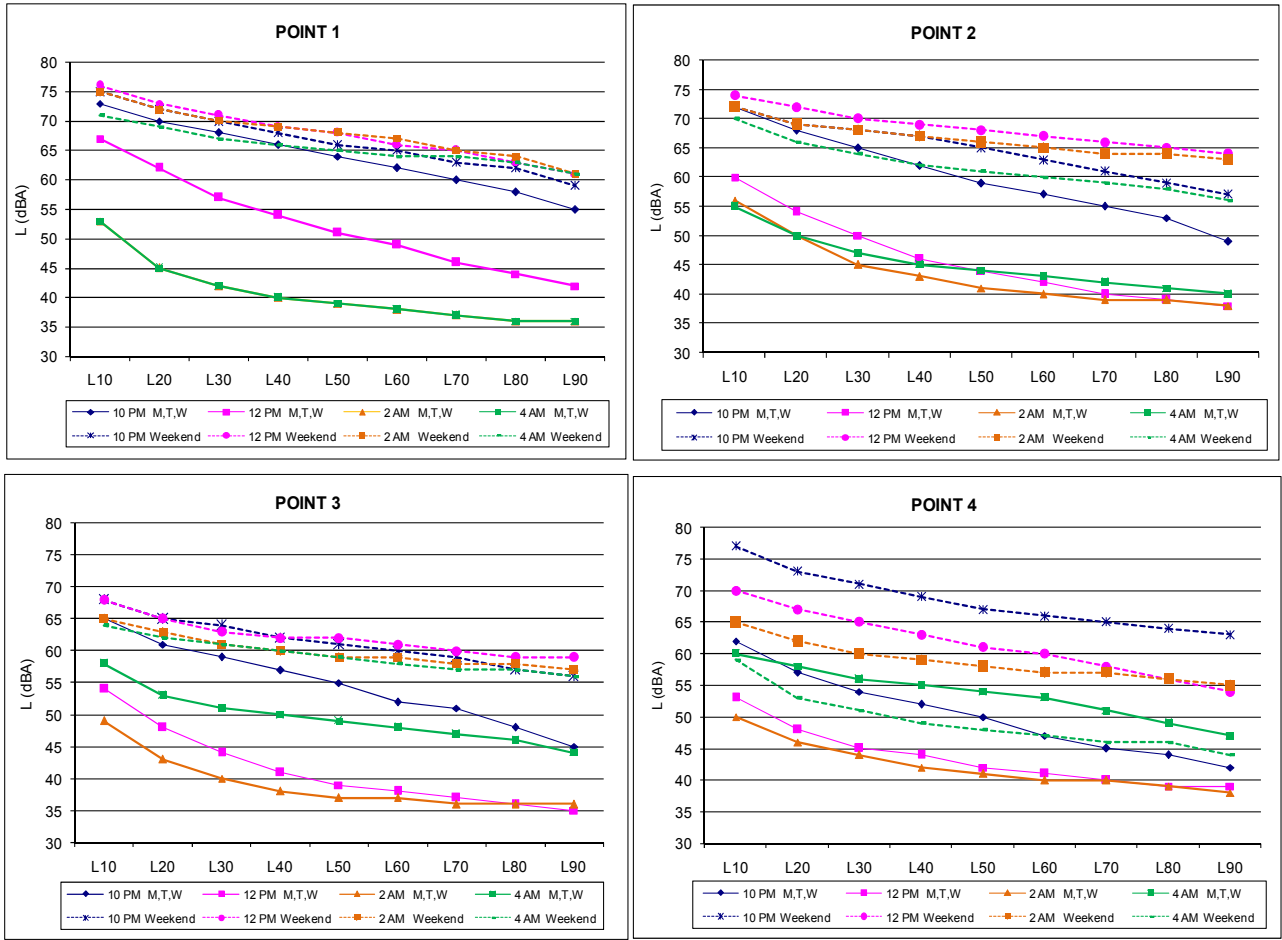

Fig. 3. Permanence curves of environmental noise levels at different points of measurement and different time, in conditions with (dotted lines) and without (full lines) nightclubs in operation.

\section{Road traffic noise characterization}

Traffic is usually considered the main noise source in the city. Many features of noise traffic are inherent to running vehicles, but others depend on traffic density, age and composition of the fleet, existence of interruptions such as traffic lights or crosswalks, driving style, among other factors. 


\subsection{Reference levels for individual vehicles}

Legislation often limits the maximum emission levels for each individual vehicle, but it does not so in a generic way to traffic noise. The standardized values for different categories of vehicles may differ from one country to another. Only to exemplify, the maximum allowed levels in countries of the European Union according to Directive 2007/34/EC are presented at table 3, while those for two-wheeled vehicles in the countries of MERCOSUR according to Technical Regulation MERCOSUR/GMC/RES. N ${ }^{\circ}$ 128/96 are presented at table 4 .

\begin{tabular}{|l|c|}
\hline Vehicle categories & Values dBA \\
\hline $\begin{array}{l}\text { 2.1.1. Vehicles intended for the carriage of passengers, and comprising } \\
\text { not more than nine seats including the driver's seat }\end{array}$ & 74 \\
\hline $\begin{array}{l}\text { 2.1.2. Vehicles intended for the carriage of passengers and equipped with more than nine } \\
\text { seats, including the driver's seat; and having a maximum permissible mass of more than 3,5 } \\
\text { tonnes and: }\end{array}$ & \multicolumn{2}{|c|}{78} \\
\hline \begin{tabular}{l} 
2.1.2.1. with an engine power of less than $150 \mathrm{~kW}$ \\
\hline 2.1.2.2. with an engine power of not less than $150 \mathrm{~kW}$
\end{tabular} \\
\hline $\begin{array}{l}\text { 2.1.3. Vehicles intended for the carriage of passengers and equipped with more than nine } \\
\text { seats, including the driver's seat; vehicles intended for the carriage of goods: }\end{array}$ \\
\hline \begin{tabular}{l} 
2.1.3.1. with a maximum permissible mass not exceeding 2 tonnes \\
\hline $\begin{array}{l}\text { 2.1.3.2. with a maximum permissible mass exceeding 2 tonnes but not } \\
\text { exceeding 3,5 tonnes }\end{array}$
\end{tabular} \\
\hline $\begin{array}{l}\text { 2.1.4. Vehicles intended for the carriage of goods and having a maximum permissible mass } \\
\text { exceeding 3,5 tonnes: }\end{array}$ \\
\hline \begin{tabular}{l} 
2.1.4.1. with an engine power of less than $75 \mathrm{~kW}$ \\
\hline 2.1.4.2. with an engine power of not less than $75 \mathrm{~kW}$ but less than $150 \mathrm{~kW}$
\end{tabular} \\
\hline \begin{tabular}{l} 
2.1.4.3. with an engine power of not less than $150 \mathrm{~kW}$ \\
\hline
\end{tabular} & 78 \\
\hline
\end{tabular}

However:

- $\quad$ for vehicles of categories 2.1.1 and 2.1.3 the limit values are increased by $1 \mathrm{dBA}$ if they are equipped with a direct injection diesel engine,

- for vehicles with a maximum permissible mass of over two tonnes designed for off-road use, the limit values are increased by $1 \mathrm{~dB}(\mathrm{~A})$ if their engine power is less than $150 \mathrm{~kW}$ and $2 \mathrm{~dB}(\mathrm{~A})$ if their engine power is $150 \mathrm{~kW}$ or more

- $\quad$ for vehicles in category 2.1.1, equipped with a manually operated gear box having more than four forward gears and with an engine developing a maximum power exceeding $140 \mathrm{~kW} / \mathrm{t}$ and whose maximum power/maximum mass ratio exceeds $75 \mathrm{~kW} / \mathrm{t}$, the limit values are increased by $1 \mathrm{~dB}(\mathrm{~A})$ if the speed at which the rear of the vehicle passes the line $\mathrm{BB}^{2}$ in third gear is greater than $61 \mathrm{~km} / \mathrm{h}$.

Table 3. Current limit values for sound level of moving vehicles in the European Union

${ }^{2}$ According with ISO standard test. 


\begin{tabular}{|c|c|c|}
\hline \multicolumn{3}{|c|}{ MERCOSUR maximum noise for stationary and accelerating vehicle } \\
\hline Category & $\begin{array}{c}1^{\text {st }} \text { phase implantation } \\
01 / 01 / 2000\end{array}$ & $2^{\text {nd }}$ phase implantation $01 / 01 / 2001$ \\
\hline Under $80 \mathrm{~cm}^{3}$ & $77 \mathrm{dBA}$ & $75 \mathrm{dBA}$ \\
\hline $81 \mathrm{~cm}^{3}$ to $125 \mathrm{~cm}^{3}$ & $80 \mathrm{dBA}$ & \multirow{2}{*}{$77 \mathrm{dBA}$} \\
\hline $126 \mathrm{~cm}^{3}$ to $175 \mathrm{~cm}^{3}$ & $81 \mathrm{dBA}$ & \\
\hline $176 \mathrm{~cm}^{3}$ to $350 \mathrm{~cm}^{3}$ & $82 \mathrm{dBA}$ & \multirow{2}{*}{$80 \mathrm{dBA}$} \\
\hline Over $350 \mathrm{~cm}^{3}$ & $83 \mathrm{dBA}$ & \\
\hline
\end{tabular}

The noise level of stationary vehicle is the reference value at the certification process of new vehicles.

Table 4. Limit values for noise levels from moving motorcycles, scooters, tricycles, mopeds, bicycles with auxiliary motor running and similar vehicles in MERCOSUR.

\subsection{Traffic noise spectrum}

The spectral composition is one of the features related to the nature of traffic noise. For a continuous traffic flow, it may be assumed that the spectral composition is in correspondence with the "standardized traffic noise spectrum" that is defined both by octave bands levels and by third octave bands levels at standard EN1793-3.

Given a noise level value expressed in $\mathrm{dBA}$, its spectral composition in octave bands or in third octave bands (also expressed in ABA) shall be found by adding band to band the set of tabulated values that define the standardized spectrum. Recommendation 2003/613/EC presents the standardized traffic spectrum in octave bands, based on the values given for third octave bands by the referred standard. Table 5 reproduces it.

\begin{tabular}{|c|c|}
\hline Octave band (en Hz) & Addition values (dBA) \\
\hline 125 & $-14,5$ \\
\hline 250 & $-10,2$ \\
\hline 500 & $-7,2$ \\
\hline 1000 & $-3,9$ \\
\hline 2000 & $-6,4$ \\
\hline 4000 & $-11,4$ \\
\hline
\end{tabular}

Table 5. Standardized spectrum of traffic noise, according to the Recommendation 2003/613/EC

\subsection{Data normality}

One feature to take especially into account, as it directly affects the data processing of urban noise, is the non-normality of time series of traffic noise levels. This had already been foreseen by Don and Rees for the city of Victoria, Australia in 1985. Even if they selected the measures duration according to the recommendations of the moment, the researchers concluded that the statistic distribution of urban traffic noise level rarely fit a Gaussian. They have affirmed: "the shape is anything but Gaussian". Their explanation for the nonnormality of the data was supported on the supposing that the urban noise should results from the superposition of four elements, and each one of them would fit or not a Gaussian distribution: noise levels produced by cars on the measurement side of the road; noise levels produced by trucks on the measurement side of the road; noise levels produced by all 
vehicles on the side of the road opposite to the measurement position; background levels that occur during the absence of vehicles (Don \& Rees, 1985). Today, the shortness of their measurements (only $400 \mathrm{~s}$ ) would be also considered as another possible way to explain the non-normality of data series.

The non-normality of traffic noise data has been reaffirmed through many years of research in various cities of different countries. It is the case of Montevideo, Rivera and Salto in Uruguay, Medellín in Colombia, Valencia and Madrid in Spain, among others (CONICYTIMFIA, 1998; Gaja et al., 2003; Giménez Sancho, 2010; González, 2000; González et al., 2007; IMM-Facultad de Ingeniería, 1999; Jaramillo et al., 2009).

\begin{tabular}{|c|c|c|c|c|c|c|}
\hline & & A & B & $\mathrm{C}$ & D & $E$ \\
\hline \multirow{2}{*}{ 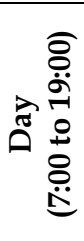 } & Best fit & $\begin{array}{c}\text { Log- } \\
\text { Logistic(3P) } \\
71,7 \%\end{array}$ & $\begin{array}{c}\text { Log- } \\
\text { Logistic(3P) } \\
40,0 \%\end{array}$ & $\begin{array}{l}\text { Cauchi } \\
23,3 \%\end{array}$ & $\begin{array}{c}\text { Log- } \\
\text { Logistic(3P) } \\
48,3 \%\end{array}$ & $\begin{array}{c}\text { Johnson SU } \\
75,0 \%\end{array}$ \\
\hline & $\begin{array}{c}\text { Gauss fit } \\
\text { and ranking } \\
\left(1^{\text {st }}-13^{\text {th }}\right)\end{array}$ & $\begin{array}{c}25,0 \% \\
12 \text { th }\end{array}$ & $\begin{array}{c}3,3 \% \\
13 \text { th }\end{array}$ & $\begin{array}{c}0,0 \% \\
13 \text { th }\end{array}$ & $\begin{array}{c}0,0 \% \\
13 \text { th }\end{array}$ & $\begin{array}{c}48,3 \% \\
6^{\text {th }}\end{array}$ \\
\hline \multirow{2}{*}{ 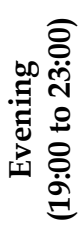 } & Best fit & $\begin{array}{c}\text { Log- } \\
\text { Logistic(3P) } \\
90,0 \%\end{array}$ & $\begin{array}{c}\text { Log- } \\
\text { Logistic(3P) } \\
95,0 \%\end{array}$ & $\begin{array}{c}\text { Laplace } \\
70 \%\end{array}$ & $\begin{array}{c}\text { Log- } \\
\text { Logistic(3P) } \\
45,0 \%\end{array}$ & $\begin{array}{c}\text { Johnson SU } \\
50,0 \%\end{array}$ \\
\hline & $\begin{array}{c}\text { Gauss fit } \\
\text { and ranking } \\
\left(1^{\text {st }}-1^{\text {th }}\right)\end{array}$ & $\begin{array}{c}20,0 \% \\
12 \text { th }\end{array}$ & $\begin{array}{c}45,0 \% \\
10^{\text {th }}\end{array}$ & $\begin{array}{c}5,0 \% \\
10 \text { th }\end{array}$ & $\begin{array}{c}0,0 \% \\
13 \text { th }\end{array}$ & $\begin{array}{c}5,0 \% \\
13 \text { th }\end{array}$ \\
\hline \multirow{2}{*}{ 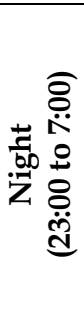 } & Best fit & $\begin{array}{c}\text { Log- } \\
\text { Logistic(3P) } \\
52,5 \% \\
\text { Beta } \\
52,5 \%\end{array}$ & $\begin{array}{c}\text { Log- } \\
\text { Logistic(3P) } \\
30,0 \%\end{array}$ & $\begin{array}{c}\text { Log- } \\
\text { Logistic(3P) } \\
32,5 \%\end{array}$ & $\begin{array}{c}\text { Log- } \\
\text { Logistic(3P) } \\
42,5 \%\end{array}$ & $\begin{array}{c}\text { Log- } \\
\text { Logistic(3P) } \\
72,5 \%\end{array}$ \\
\hline & $\begin{array}{c}\text { Gauss fit } \\
\text { and ranking } \\
\left(1^{\text {st }}-13^{\text {th }}\right)\end{array}$ & $\begin{array}{c}40,0 \% \\
9 \text { th }\end{array}$ & $\begin{array}{c}20,0 \% \\
5 \text { th }\end{array}$ & $\begin{array}{c}12,5 \% \\
7 \text { th }\end{array}$ & $\begin{array}{c}7,5 \% \\
7 \text { th }\end{array}$ & $\begin{array}{c}12,5 \% \\
8 \text { th }\end{array}$ \\
\hline
\end{tabular}

Table 6. Statistical distribution fit of noise data. Own elaboration based on Giménez Sancho's data.

Giménez Sancho determined that the adjustment of urban noise data from five consecutive years taken in the city of Madrid were "anything but Gaussian", as Don and Rees said (Giménez Sancho, 2010). Table 6 presents the percentages of samples for each time of the day and for each one of the five points considered by Giménez Sancho that fit a Gaussian distribution. In each case, the statistical distribution that fits the best (among the 13 distributions he has studied) is mentioned. The ranking of the Gaussian distribution from the best fit (numbered $1^{\text {st }}$ ) towards the worst one (numbered $13^{\text {th }}$ ) is also presented.

The most immediate consequence of the non-normality of the data is provided by the statistical restrictions for their processing, as it is not possible to use parametric or Gaussian statistics. The arithmetic mean does not make sense as such, nor does the variance or standard deviation (Sachs, 1978). Then, to compare time series of noise data or to try to fix reliable values for the permanence levels based on those observed in several measurements, 
first of all it is needed to verify if the data sets that are statistically comparable to a confidence level selected in advance. The preferred tests to run in this data process stage are Mann-Whitney test for two samples and Kruskal-Wallis test for more than two samples (González et al., 1997; González, 2000).

\subsection{Anomalous events}

There are some characteristic noises that appear in different cities, specially in LatinAmerica, and that are the so called "anomalous events". These are noisy events that are not included in the international concept of traffic noise, that refers to engine and tyre noise. This name, as much as the concept of anomalous event, was initially developed for the city of Montevideo, while it was needed to designate these elements that were not rigorously treated in the scientific literature of the moment (CONICYT-IMFIA, 1998; González et al., 1997). Later, this concept and its name have been adopted by other researchers in different countries.

An "anomalous event" can be defined in a subjective or in an objective way. The anomalous events subjectively detected are those which the ear does not recognize as engine or tyre noise, as claxons (horns), alarms, barking, sirens, violent braking, exhaust of noisy motorcycles and other noisy vehicles.

There are also so called "evitable anomalous events", which only include noisy motorcycles, claxons (horns), and loud exhaust and braking noises. A right preventive maintenance of the vehicles should cooperate to significantly reduce their occurrence, but that is not all: a proper control system is also needed. Therefore, avoiding this kind of anomalous events could reduce noise levels in about $4 \mathrm{~dB}$ in many points of Montevideo city, Uruguay (González, 2000; IMM-Facultad de Ingeniería, 1999).

\subsection{Acoustically anomalous events}

When stationary instruments are installed to monitor environmental noise, usually there is no permanent human assistance in the place. So, in order to identify whether an anomalous event is "acoustically anomalous" in a data series, an objective criteria for its identification should be developed. In Montevideo city, the definition of an acoustic anomalous event or objective anomalous event emerges from the below detailed procedure (González, 2000):

1. Calculate the $\mathrm{L}_{\mathrm{Aeq}}$ of one hour $\left(\mathrm{L}_{\mathrm{Aeq}}, \mathrm{h}\right)$ using the $60 \mathrm{~L}_{\mathrm{Aeq}, \mathrm{i}}$ data from each minute of the hour.

2. List the $60 \mathrm{~L}_{\text {Aeq,i }}$ data from each minute of the hour, from highest to lowest.

3. Cut the 12 highest values of $\mathrm{L}_{\text {Aeq }, \mathrm{i}}$.

4. Recalculate the hourly $\mathrm{L}_{\text {Aeq }}$ only using the 48 remaining $\mathrm{L}_{\mathrm{Aeq}, \mathrm{i}}$. This new value will be called $\mathrm{L}_{\text {Aeq, }}$ h, corrected.

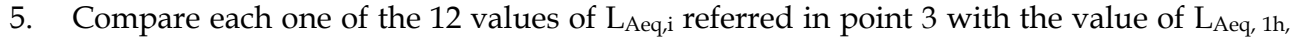
corrected obtained in point 4.

6. Every one of the with the 12 values of $L_{A e q, i}$ referred in point 3 that exceed in $4 \mathrm{~dB}$ or more the level of the $\mathrm{L}_{\mathrm{Aeq}}, 1 \mathrm{~h}$, corrected is said to correspond to an acoustically anomalous minute, in what it may have occurred at least one acoustically anomalous event.

The relationship between the number of these events in an hour and the total traffic in that hour fit a potential curve, with a correlation coefficient $\mathrm{R}^{2}=0,8679$. Then, the predictive equation for traffic noise levels in Montevideo city, obtained from 1361 noise samples, is (González, 2000): 


$$
\mathrm{L}_{\mathrm{A}, \mathrm{eq}, 1 \text { hora }}=49,4+10 \log (\mathrm{A}+2,33 \mathrm{M}+9,01 \mathrm{O}+6,84 \mathrm{C})+23,266 \mathrm{Q}^{-0.3811}-10 \log \mathrm{d}
$$

where:

M $\mathrm{N}^{\circ}$ of motorbikes per hour

A $\mathrm{N}^{\circ}$ of light cars per hour

$\mathrm{O} \quad \mathrm{N}^{\circ}$ of buses per hour

C $\mathrm{N}^{\circ}$ of trucks per hour

$\mathrm{Q}=\mathrm{M}+\mathrm{A}+\mathrm{O}+\mathrm{C}$

$\mathrm{D}$ distance to the axis of the street $(\mathrm{m})$

If traffic speed exceeds $60 \mathrm{~km} / \mathrm{h}$, then a linear correction should be added: $(15 \mathrm{v}-8,67)$, with $\mathrm{v}$ expressed in km/h (González, 2000).

\subsection{Measurement stabilization time}

The anomalous events strongly affect the lasting of measures needed to obtain a reliable sample of urban noise. As well as a low traffic density (for example, at night) cannot be trusted to select a measurement time of less than an hour to represent the hourly $\mathrm{L}_{\text {Aeq, }}$ anomalous events may also enlarge the measurement time both during the day time and the night time (González, 2000).

To exemplify, if only traffic density is taken into account, the selected measurement time for traffic noise measurements in Montevideo city would be about 15 minutes. But if the occurrence of anomalous events is also considered, then the recommended measurement time should shift to 30 minutes. Indeed, in every sample of urban noise in the city of Montevideo, it is expected to register an average amount of 9 to 12 subjective anomalous events (that is, an anomalous event every 5 or 6 minutes) but only about 4 acoustic anomalous events (González, 2000).

Then, in order to avoid selecting an excessively short measurement time, which might not be representative of the real situation, or a too long time that might turn too expensive the fieldwork, the basic concept to work with is the "measurement stabilization time". The stabilization time of a noise sample of $\mathrm{N}$ minutes is the minimum number $n$ of minutes after which the $\mathrm{L}_{\mathrm{Aeq}, \mathrm{n}}$ accumulated until that moment differ from the $\mathrm{L}_{\mathrm{Aeq}, \mathrm{N}}$ of the whole event of $\mathrm{N}$ minutes by less than a certain $\varepsilon$. The value of $\varepsilon$ strongly affects the results, and depends on the precision required according to the objective of the measurements (González, 2000).

This expression is valid for all $\mathrm{n} \geq \mathrm{T}_{\text {estab}}$, where $\mathrm{N}$ is the total number of minutes (data) in the whole sample:

$$
\left|10 \times \log \left(\frac{1}{N} \sum_{i=1}^{N} 10^{0,1 L_{i}}\right)-10 \times \log \left(\frac{1}{n} \sum_{i=1}^{n} 10^{0,1 L_{i}}\right)\right|<\varepsilon
$$

If $\varepsilon=1 \mathrm{~dB}$ is adopted for Montevideo city (that means the cumulative $\mathrm{L}_{\mathrm{Aeq}}$ of the event fluctuate from that moment until the end of the measurement in the range of $\pm 1 \mathrm{~dB}$ ) measurements lasting at least 30 minutes are required to reach the stabilization in a minimum of $90 \%$ of the samples (González, 2000).

\section{The acoustic maps as urban management tools}

According to the definition of the Directive 2002/49/EC from the European Union, a noise map is "the presentation of data on an existing or predicted noise situation in terms of a noise 
indicator, where the trespassing of any relevant regulation limit value will be indicated, also the number of people affected in a specific area or the number of households exposed to certain values of a selected noise indicator in a specific area". It is stated that the information to the public should be given in a clear, comprehensible and easily accessible way, but the information to the authorities should be much more detailed and vast. It should include other elements such as baseline information used to construct the maps, how that information was obtained, methods employed for measurement or calculation, and -obviously-charts, which are a key part of the map.

Obtaining the information to build a noise map involves a lot of detailed field and office work. Then, if all the generated information is incorporated to the map, it will turn into a management tool that shall support a variety of uses. In fact, although the definition of "noise map" is precise and comprehensive, many diverse maps should be in practice considered under this generic designation, from diagnosis to specific exposed population maps, from acoustic conflicts maps to strategic noise maps, among others. That is due to their easy comprehension for every training level of people, which make them suitable as a tool for communicating information about noise levels, as well as other kind of information (specially about environmental issues).

Annoyance maps deserve to be treated separately, since they involve penalizing the registered noise levels according to some of their characteristics, such as its impulsiveness, the presence of pure tones or high energy contents at low frequencies, among others. These maps can help to diagnose not only annoyance but also health risks (González, 2011).

To build action plans with basis on these maps, the economic value of the environmental quality from the point of view of the citizens would be determined. Even if it is not easy, it is needed to assign monetary values to people health, annoyance, loss of intellectual performance, time lost at work, property value, among other variables. The application of surveys to detect the willingness to pay for improving the acoustic quality of the environment is a desirable way to obtain these data. Therefore, this kind of work does not only provide a monetary quantification to assess the impact of different measures to be applied in an area or, conversely, the impact that one measure might have on different areas, but it also allows for prioritization of different possible interventions. When similar reductions of environmental noise levels and similar number of benefited people are considered as consequences of different possible interventions, the most adequate one to initiate a program of actions to fight noise is that one which will be repaid sooner by the people willingness to pay for (González, 2011).

One of the most relevant applications nowadays is the acoustic mapping aimed for developing strategic plans for acoustics decontamination. As stated by the above mentioned Directive, a strategic noise map is "a map designed for the global assessment of noise exposure in an area due to the existence of different noise sources or in order to make global predictions for the area." As the noise maps that are built for other purposes, strategic maps must also include graphic material (charts) and detailed technical reports, in order to fulfill their original purpose. González García emphasizes, among other thematic maps that can be part of a strategic noise map: maps of noise level indicators; maps of affected areas (that show the areas where $\mathrm{L}_{\mathrm{den}}$ is above $55 \mathrm{dBA}, 65 \mathrm{dBA}$ and $75 \mathrm{dBA}$ ); maps of exposure at facade of buildings (the noise levels are taken at a height of $4 \mathrm{~m}$ ); maps of exposed people; maps of land use and acoustic zoning; maps of carrying noise capacity; maps of noise sensitivity (González García, 2006). 
Since the enactment of Directive 2002/49/EC, strategic noise maps should be built for all cities of more than 250.000 inhabitants in the member countries. Their results have to be informed to the Council of the European Union, to implement concrete actions in order to improve the acoustic environment quality, and to ensure the review and renew of the strategic maps with a minimum frequency.

After 10 years, although there are still difficulties with its implementation and to harmonize working methods, the applicability of strategic noise maps cannot be doubted (Sanz Sa, 2010). In fact, there are many national and provincial standards that regulate the obligation to have strategic noise maps in towns that exceed a certain number of inhabitants, that may be much fewer than the 250.000 inhabitant mentioned by the Directive (to exemplify, noise Law 5/2009 of Castilla and León, Spain, states strategic noise maps for all towns with 20.000 inhabitants or more, less than $10 \%$ of the minimum number of inhabitants considered by the European Union Directive).

Regarding regulations, the situation in Latin America is very different. Colombia is the only Latin American country that has in its current national legislation (Resolution 0627, 2006), a requirement about building noise maps, but for another urban scale: the maps are asked for for cities of more than 100.000 inhabitants. No other Latin-American country has currently noise regulations with similar requirements.

In Argentina, the Research Team on Acoustics from the Laboratorio de Acústica y Luminotecnia CIC-LAL, Buenos Aires, has been elaborating regulations proposals since 2002. In the latest version, the necessity to carry out an acoustic plan for those urban areas that exceed 25.000 inhabitants is mentioned and the minimum contents of these plans are referenced. The requirement of building acoustic maps has been removed in this version while it was present in previous ones. Although it may be discussed whether this is the best way to build a noise decontamination plan, this decision was needed because of the controversies aroused in the Parliament to force small towns to do an investment to have their acoustic maps (Velis et al., 2009).

The situation in Uruguay is even farther: nowadays there is no noise regulation of national scope, and none of the departmental ordinances even mention acoustic maps (González et al., 2008; González, 2010a).

Regarding the strategic noise maps, Bañuelos has stated: "The matter is not only offering more or less colorful images". To be useful, the information presented in a strategic noise map must be realistic and representative. The high initial cost for the Administration related to a strategic noise map is not due to building the map, but to the costs of implementing the corrective measures that may be needed in consequence (Bañuelos Irusta, 2008).

It should be always taken into account that the charts of an acoustic map, regardless of the target that it has aimed to fulfill, should always be based on solid and comprehensive technical documentation, to give credibility to the exposed information. Not only its reliability becomes widely increased, but also its possible applications get greatly expanded (González, 2011).

\section{Conclusion}

Noise management involves great challenges: if one problem has seemed easy to solve, certainly it has not been raised properly. 
To influence on politics about noise and to improve environmental acoustic quality, academic research must focus on the main concerns of the society, trying to understand these issues and to build better sustainable management proposals.

\section{References}

Bañuelos Irusta, A. (2008) Mapa de ruido: herramienta para la evaluación y gestión del ruido. Proceedings of International Seminar on Environmental Noise. ISBN: 978-958-443029-8, Medellín, Colombia, March 2008.

Beristáin, S. (1998) El ruido es un serio contaminante, Proceedings of 1st Iberoamerican Congress on Acoustics, Florianópolis, Brazil, March 1998.

Beristáin, S. (2010) Noise in the largest Mexican city, 2nd Pan-American and Iberian Meeting on Acoustics, 160th ASA meeting, $7^{\circ}$ Congress FIA, $17^{\circ}$ Congress IMA, ISSN: 0001-4966, Cancún, México, November 2010.

Brito, A. (2011a) O triângulo dos eventos públicos em Fortaleza, Poluição Sonora em Fortaleza, 2011, available on line at aureliobrito.blogspot.com/

Brito, A. (2011b) 24 horas na vida de quem sofre com poluiçao sonora, In: Poluição Sonora em Fortaleza, 2011, available on line at aureliobrito.blogspot.com/

Colegio Oficial de Ingenieros Superiores Industriales de la Comunidad Valenciana (2004) Contra los ruidos. InfoIndustrial, No 31, (abril 2004), pp. 6-7.

CONICYT-IMFIA González, A.E., Perona, D.H., Martínez Luaces, V., Barbieri, A., Gerardo, R., Guida, M., López, J., Maneiro, M. (1998) Contaminación sonora en ambiente urbano, Informe Final del Proyecto de Investigación CONICYT - Clemente Estable 2040, Montevideo, Uruguay, 1998.

Defensor del Pueblo de Madrid (2005) Informes, estudios y documentos, Contaminación Acústica, ISBN: 84-87182-48-8, Madrid, Spain.

Defensoría del Vecino de Montevideo (2010) Cuarto Informe Anual Año 2010, Montevideo, Uruguay.

Diario El País, CADENASER.COM 09-02-2007. Available on line (2011) at www.elpais.com

Don, C.G. \& Rees, I.G. (1985) Road traffic sound level distributions, Journal of Sound and Vibration, 100(1), (1985), pp. 41-53. ISSN : 0022-460X.

Gaja Díaz, E., Reig, A. Sancho, M., González, E. (1998) Evolución del nivel de Ruido Ambiental en la ciudad de Valencia. Acciones de control. Proceedings of 1st Iberoamerican Congress on Acoustics, Florianópolis, Brazil, March 1998.

Gaja, E., Giménez, A., Sancho, S., Reig, A. (2003) Sampling techniques for the estimation of the annual equivalent noise level under urban traffic conditions, Applied Acoustics, 64 (2003) pp.43-53. ISSN : 0003-682X.

Giménez Sancho, A. (2010) Contribución al estudio de los índices europeos de valoración del ruido ambiental en ambiente urbano, Doctoral Thesis, Universidad Politécnica de Valencia, Valencia, Spain, June 2010.

Giraldo Arango, J.M. (2008) Control del ruido en la construcción de obras públicas, Proceedings of International Seminar on Environmental Noise. ISBN: 978-958-44-3029-8, Medellín, Colombia, March 2008.

González, A.E., Gaja, E., Martínez Luaces, V., Gerardo, R., Reig Fabado, A. (1997) Niveles de Contaminación Sonora en la ciudad de Montevideo, Proceedings of the Congress of the Acoustics Society of Spain Tecniacústica '97, Oviedo, Spain, November 1997. 
González, A.E. (2000) Monitoreo de ruido urbano en la ciudad de Montevideo: determinación del tiempo óptimo de muestreo y desarrollo de un modelo predictivo en un entorno atípico. Thesis for the Degree of Doctor in Environmental Engineering, UdelaR, Montevideo, Uruguay, March 2000.

González, A.E., Paulino, D., Tironi, M. (2006) Incidencia de actividades recreativas nocturnas sobre la calidad acústica del entorno en la ciudad de Salto (Uruguay), XXX Iberoamerican Congress of AIDIS Internacional, Punta del Este, Uruguay, November 2006.

González, A.E.; Gavirondo, M., Pérez Rocamora, E., Bracho, A. (2007) Urban noise: measurement time and modelling of noise levels in three different cities. Noise Control Engineering Journal, 55 (3), (May-June 2007), pp. 367-372. ISSN 0736-2501.

González, A.E., Echeverri Londoño, C.A. (2008) Locales de diversión nocturna y contaminación sonora. In: Actas FIA 2008, VI Iberoamerican Congress on Acoustics FIA 2008, compiled by Federico Miyara, ISBN 978-987-24713-1-6, Buenos Aires, Argentine, November 2008.

González, A.E., Indarte E. \& Lisboa, M. (2008) Acústica Urbana. Memorias de las Jornadas de Convergencia en Normativa de Contaminación Acústica, Convenio MVOTMA - UdelaR (DINAMA - Facultad de Ingeniería), ISBN 978-9974-0-0541-9, Montevideo, Uruguay.

González, A.E. (2010a) Which are the main management issues about noise in Uruguay 2010? 2nd Pan-American and Iberian Meeting on Acoustics, 160th ASA meeting, $7^{\circ}$ Congress FIA, $17^{\circ}$ Congress IMA, Cancún, México, November 2010. ISSN: 0001-4966

González, A.E. (2010b) Mediciones de niveles sonoros ambientales y ocupacionales en obras civiles, DIA-IMFIA Facultad de Ingeniería, UdelaR.

González, A.E. (2011) Mapas acústicos: Mucho más que una cartografia coloreada. Latinoamerican Conference AES 2011, Montevideo, Uruguay, August 2011.

González García, M.A. (2006) ¿Qué es y cómo se hace un mapa estratégico de ruido en carreteras? Proceedings of Tecniacústica 2006, Gandía, Spain, October 2006.

IMM - Facultad de Ingeniería (1999) Mapa Acústico de Montevideo, Informe Final del Convenio, Montevideo, Uruguay.

Jaramillo, A., González, A., Betancur, C., Correa, M. (2009) Estudio comparativo entre las mediciones de ruido ambiental urbano a 1,5 m y $4 \mathrm{~m}$ de altura sobre el nivel del piso en la ciudad de Medellín, Antioquia - Colombia. Revista Dyna, 157 pp. 71-79. ISSN 0012-7353.

Kotzen, B. \& English, C. (2009) Environmental noise barriers: a guide to their acoustic and visual design, $2^{\text {nd }}$ ed. ISBN 10: 0-203-93138-6.

Laboratorio de Acústica y Electroacústica, Escuela de Ingeniería Electrónica, Universidad Nacional de Rosario (2011) Available on line at the oficial Web site http://www.fceia.unr.edu.ar/acustica/

Lizana, P. (2010) Enviromental noise culture, 2nd Pan-American and Iberian Meeting on Acoustics, 160th ASA meeting, $7^{\circ}$ Congress FIA, $17^{\circ}$ Congress IMA, ISSN: 0001-4966, Cancún, México, November 2010.

Madariaga Coaquira, Z. (2008) El ruido ambiental en la ciudad de Arequipa y su incidencia en la salud de la población más expuesta, Proceedings of International Seminar on Environmental Noise. ISBN: 978-958-44-3029-8, Medellín, Colombia, March 2008. 
Miyara, F. (2007) "Ruido, juventud y derechos humanos". I Congreso Latinoamericano de Derechos Humanos. Rosario, Argentine, 2007.

Miyara, F. (2008) Ruido Urbano: tránsito, industria y esparcimiento, In Acústica urbana. Módulo I. Manual de mediciones acústicas orientado a la gestión municipal, Convenio MVOTMA - UdelaR (DINAMA - Facultad de Ingeniería), ISBN 978-9974-7610-2-5, Montevideo, Uruguay.

Observatorio de las novedades acústicas y musicales, Coches que no hacen ruido, 2010, available on line (2011) at http://www.acusticaweb.com/blog/acustica-ambiental-y-ruido/

Orozco-Medina, M.G., Figueroa-Montaño, A. (2010) Urban noise and transport as a strategy of environmental quality, 2nd Pan-American and Iberian Meeting on Acoustics, 160th ASA meeting, $7^{\circ}$ Congress FIA, $17^{\circ}$ Congress IMA, ISSN: 0001-4966, Cancún, México, November 2010.

Posada, M.I., Arroyave, M., Fernández, C. (2009) Influencia de la vegetación en los niveles de ruido urbanos, Revista EIA, 12 (December 2009), pp. 79-89, ISSN 1794-1237

Ríos Valencia, O. (2008) Niveles de ruido sobre la franja horaria del pico y placa, municipio de Medellín, Proceedings of International Seminar on Environmental Noise. ISBN: 978958-44-3029-8, Medellín, Colombia, March 2008.

Sachs, L. (1978) Estadística Aplicada, Editorial Labor, Spain.

Sáenz Cosculluela, I. (2004) Keynote speech at the I Congreso Nacional contra el Ruido: ruido, salud y convivencia, PEACRAM, Plataforma Estatal contra el Ruido, Zaragoza, Spain, April 2004.

Sanz Sa, J.M. (2010) Experiencia de la $1^{\text {a }}$ fase de los MER y Perspectivas para la $2^{\circ}$ fase. I Jornada Acústica: Desarrollo Normativo en Acústica Ambiental, Cádiz, Spain, November 2010.

Velis, A.G., Rizzo la Malfa, A.M., Bontti, H., Vechiatti, N., Iasi, F., Armas, A., Tomeo, D. (2009) Evolución del Proyecto de Ley de Protección Ambiental de la Calidad Acústica en la Provincia de Buenos Aires. First Regional Conference on Acoustics from AdAA, Rosario, Argentine, November 2009. 


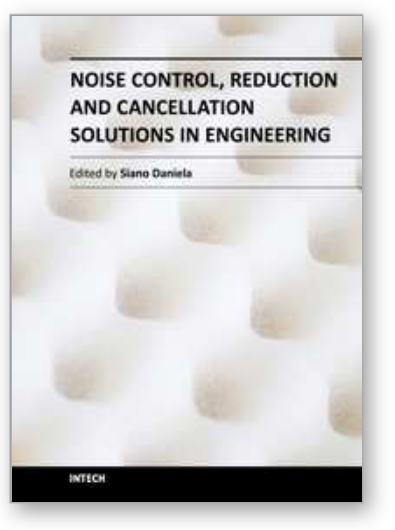

\author{
Noise Control, Reduction and Cancellation Solutions in \\ Engineering \\ Edited by Dr Daniela Siano
}

ISBN 978-953-307-918-9

Hard cover, 298 pages

Publisher InTech

Published online 02, March, 2012

Published in print edition March, 2012

Noise has various effects on comfort, performance, and human health. For this reason, noise control plays an increasingly central role in the development of modern industrial and engineering applications. Nowadays, the noise control problem excites and attracts the attention of a great number of scientists in different disciplines. Indeed, noise control has a wide variety of applications in manufacturing, industrial operations, and consumer products. The main purpose of this book, organized in 13 chapters, is to present a comprehensive overview of recent advances in noise control and its applications in different research fields. The authors provide a range of practical applications of current and past noise control strategies in different real engineering problems. It is well addressed to researchers and engineers who have specific knowledge in acoustic problems. I would like to thank all the authors who accepted my invitation and agreed to share their work and experiences.

\title{
How to reference
}

In order to correctly reference this scholarly work, feel free to copy and paste the following:

Alice Elizabeth González (2012). Noise Sources in the City: Characterization and Management Trends, Noise Control, Reduction and Cancellation Solutions in Engineering, Dr Daniela Siano (Ed.), ISBN: 978-953-307-9189, InTech, Available from: http://www.intechopen.com/books/noise-control-reduction-and-cancellationsolutions-in-engineering/noise-sources-in-the-city-characterization-and-management-trends-

\section{INTECH}

open science | open minds

\author{
InTech Europe \\ University Campus STeP Ri \\ Slavka Krautzeka 83/A \\ 51000 Rijeka, Croatia \\ Phone: +385 (51) 770447 \\ Fax: +385 (51) 686166 \\ www.intechopen.com
}

\author{
InTech China \\ Unit 405, Office Block, Hotel Equatorial Shanghai \\ No.65, Yan An Road (West), Shanghai, 200040, China \\ 中国上海市延安西路65号上海国际贵都大饭店办公楼 405 单元 \\ Phone: +86-21-62489820 \\ Fax: $+86-21-62489821$
}


(C) 2012 The Author(s). Licensee IntechOpen. This is an open access article distributed under the terms of the Creative Commons Attribution 3.0 License, which permits unrestricted use, distribution, and reproduction in any medium, provided the original work is properly cited. 